\title{
Assessing service failure recovery strategies and its impacts upon service quality offered: management perspective in local Fast food restaurants
}

\author{
Nabeel Aly Aly Ahmad Badran Magdy Abdel Aleem Abdela'tty \\ Faculty of Tourism and Hotels, Fayoum University
}

\begin{abstract}
The aim of this research paper is to assess the service failure recovery strategies adopted by local fast food restaurant in Egypt and recommend specific strategies that restaurant's managers and customers agreed on. A questionnaire form was used to collect data from two categories of respondents; the first category comprised local fast food restaurants' managers and servers. Ten local fast food chains were surveyed as a comprehensive sample (149 restaurants). A total of 123 successful responses were achieved with a response rate of $82.55 \%$. The second category comprised local fast food restaurants' customers to assess their beliefs about the same variables that managers had earlier reported on. A total of 171 successful responses were achieved out of 250 with a response rate of $68.4 \%$. The findings indicate the importance of service recovery that facilitates transforming behavioral intentions into actual behavior.
\end{abstract}

Keywords: Purchase intentions, Relationship quality, Purchase behavior, Service recovery satisfaction, quality of service, hotel industry.

\section{Reviewing of literature}

\subsection{Introduction}

Barbara \& Spyrakopoulos (2001) indicated that in service industries, quality discrepancies and shortfalls are likely to occur, especially when human input is largely responsible for the production and delivery of the offering. In essence, Swanson \& Kelley (2001) added that customers are valuable assets. Modern customers are ever more demanding in their interactions with service providers due to the increased abundance of choices (Casado, 2011).

Moreover, Lewis et al. (2006) contended that as customers become increasingly happy to complain about a service, so it has become more important to organizations to deal efficiently with angry customers to maintain customer loyalty (Magnini \& Ford, 2004). An example is Hampton Inn, the US hotel chain, which realized \$11 million in additional revenue from the implementation of an effective service guarantee, and highest customer retention (Mack et al., 2000).

Emerging from these considerations and facts, Primo et al. (2007) argued that the on-going relationship between the organization and customer is important to the two parties. A healthy relationship is vital because it encourages information sharing, useful communication (Magnini et al., 2007) and more trust. This interaction improves planning, coordination, problem solving, and adaptation. So, it is important to the organization to react to service failures and recoveries to cut significant costs. In addition, Johnston \& Michel (2008) emphasized that managing complaints well and recovering customers, i.e. dealing with them after a service failure and a complaint, should be the cornerstone of an organization's customer satisfaction strategy. Service failure recovery is a planned process for returning aggrieved customers to a state of satisfaction (Harris et al., 2006) with the firm after a service or product had failed to live up to their expectations by solving problems before customers complain or leave the service organization dissatisfied (Seawright et al., 2008).

\subsection{Benefits of service failure recovery}

Seawright et al. (2008) emphasized that organizations cannot ignore the significant costs that result when customers are lost. Research demonstrates that the average customer who faces a problem with an organization tells nine other people about the failure and of course this is a negative word of mouth.

Besides, service recovery procedures can be viewed as expensive but, they should be viewed as an opportunity to make improvements which will lead to cost reductions, through the removal of ineffective operations, and also to fewer failures in the future (Johnston \& Michel, 2008). Lewis et al. (2006) contended that establishing service-recovery guidelines and standards are crucial procedures to maintain process 
recovery which thereby influence the overall profitability of the organization (Bamford \& Xystouri, 2005). In addition, Santos-Vijande et al. (2013) argued that failure management achieves a strategic consideration since it involves a profound revision of overall organization processes and the organizational commitment to proactively prevent failures, efficiently recover and learn from mistakes, successfully maintain long-term customer relationships and attain competitive advantages (La \& Kandampully, 2004).

Primo et al. (2007) stated that recovery is an opportunity for managers to redeliver a service in a way that customers could be more loyal to the organization than customers who have not faced failures and enhance the image of processes of the organization. Also, a good service recovery enhances customers' perceptions of the firm's competence, improves recovery procedures and recovery training, and improves the bottom line (Swanson \& Kelley, 2001).

Nguyen et al. (2012) indicated that loss of customers typically result in substantial financial and reputation loss so; service recovery solutions will increase customer satisfaction and repurchase intentions (Hess $\mathrm{Jr}$, 2008) if they match customer expectations of the recovery. Moreover, Zhou (2013) argued that an effective recovery is critical for organizations because it not only can compensate for consumers' losses but also may result in a positive word-of-mouth (WOM) (Lin et al., 2011; de Matos et al., 2009; Weun et al., 2004), repurchase and loyalty.

\subsection{Dimensions of service failure recovery}

Primo et al. (2007) stated that recovery speed, employee involvement and managerial intervention are vital factors in customer evaluations. Hassles and delays during the recovery process are negative factors. Psychological activities such as apology and supplier employees' empathy (Du et al., 2010) and courtesy in recovering, affect positively customer satisfaction.

On the other hand, Barbara \& Spyrakopoulos (2001) Service failure recovery system depends basically on Employee responses to customer needs, such as customer preferences and admitted customer error (Palmer et al., 2000), employees' responses to service failures, such as unavailable or slow service, the attention paid to the customer and performance under adverse circumstances, problem customers, encompassing lack of cooperation, verbal abuse and drunkenness, service provider error, customer error and associated organization error.

In addition, Casado (2011) divided organizational responses to service failures into six dimensions: timeliness (speed of handling a complaint), facilitation (procedures to handle complaints), redress (benefits received), apology (acknowledgment of the complainant's distress), credibility (explanation for the problem) and attentiveness (interpersonal communication with the customer).

\subsection{Service failure recovery strategies:}

Johnston \& Michel (2008) emphasized three basic service failure strategies. Any recovery efforts should spotlight on these prime recovery strategies.

A- Customer recovery strategy: how to satisfy the customer following a failure and assess the impact of recovery on loyalty, delight and profit. Recovering the customer involves seven key activities:

(1) Acknowledgement. the management should acknowledge that a problem has actually occurred.

(2) Empathy. The management should understand the problem from the customer's point of view (Seawright et al., 2008).

(3) Apology. Saying sorry and showing regret are crucial (Zhou et al., 2013).

(4) Own the problem. Taking ownership of the customer and the issue is a necessary action here.

(5) Fix the problem. The management should fix the problem for the customer (Forbes, 2008).

(6) Provide assurance. Providing assurance that the problem has been/will be sorted and should not occur again is the core of this activity (Primo et al., 2007).

(7) Provide compensation. Providing a refund or compensation depending on the severity of the problem is important (Dutta et al., 2007, Hoffman et al., 2003). 


\section{B- Process recovery strategy:}

Process improvement is what many customers wish to see happen. The prime customer expectation is to have the failure fixed not just for themselves but for future customers. The organization should use the data gleaned from the failure and its consequences to drive improvements through an organization by focusing managerial attention on specific problem areas (Chung-Herrera, 2010). Learning from failures moves service recovery away from a transactional activity toward management activity that improves systems and processes to ensure future customers are happy and costs are decreased. Process improvements that influence customer satisfaction represent the most significant means of creating bottom-line impacts through recovery (Suk et al. 2009).

Process improvement involved four key stages:

(1) Data collection. Collecting data about both complaints and operational recovery procedures is vital, so data about problem areas are made available to management (Battaglia et al.,2012).

(2) Data analysis. Analyzing data is crucial to identify problems and set priorities through specific results and conclusions (Edvardsson et al., 2011).

(3) Costing. The management should assess the cost and other implications of correcting or improving different related processes.

(4) Improvement. Improving the operational and organizational processes and assessing the impact after implementation of such improvements are so vital.

The adoption of total quality management (TQM), mystery shopping and the use of the critical incident technique, ISO 9000 certification, national quality award schemes, and application of six sigma methodologies are to be the key methods to detect service failures and collect information about them. They help in identifying error-prone processes and can also be useful for staff training (Mattila, 2001) and for establishing service benchmarks.

\section{C- Employee recovery strategy:}

A critical element in service recovery procedures is the front-line employees who deal with complaining and sometimes highly emotional customers (Komunda \&Osarenkhoe, 2012). They often find themselves sandwiched between understandable customer grievances and unchangeable organizational policies and procedures. Their role represents their ability to adapt, to be proactive and the role of self-managing teams.

Employee behavior was a more important factor in the recovery process and if he was alienated and compounded, this alienation would influence directly the customers, especially aggrieved ones. Other actual or potential threats to employees' self-esteem, reputation, autonomy, resources, and job security lead to the suppression of information. Consequently, a lack of employee recovery leads to both poor customer recovery and poor process recovery. Conversely, combining employee recovery with process recovery can lead to superior customer recovery. Lewis et al. (2006) emphasized that the employee is more capable and willing to provide a higher quality of customer care if he or she is happy with the work being undertaken. A happy customer, seemingly, begins with a happy employee. The training and empowerment of employees (Ozgen \&Kurt, 2012; Cunha et al. 2009), or employee support aids in the recovery of employees as internal clients, since they develop a better ability to avoid failures and to take responsibility for service recovery when a failure does happen.

\section{Aim and objectives of the Study}

The aim of this research is to asses the service failure recovery strategies adopted by local fast food restaurant in Egypt and recommend specific strategies that restaurant's managers and customers agreed on.

Consequently, the following objectives have been;

1. To identify the benefits of service failure recovery strategies in the restaurant sector;

2. To identify service failure types that usually occur in local fast food restaurants in Egypt;

3. To assess the service failure recovery strategies adopted by local fast food restaurants and;

4. To recommend specific recovery strategies to recover service failures that occur in local fast food restaurants. 


\section{Hypotheses of the Study}

H1: there are no significant differences between management strategies of Customer recovery adopted in local fast food restaurants and the perceptions of guests towards the Customer recovery strategy.

H2: there are no significant differences between management strategies of Process recovery adopted in local fast food restaurants and the perceptions of guests towards the Process recovery strategy.

H3: there are no significant differences between management strategies of Employee recovery adopted in local fast food restaurants and the perceptions of guests towards the Employee recovery strategy.

\section{Methods of the research}

\subsection{Research approach}

According to the aim of this study, the research used a deductive research approach. The research used three hypotheses to explain the differences between management strategies of service failure recovery adopted in local fast food restaurants and the perceptions of guests towards these strategies. Quantitative methods were used to investigate these hypotheses including compare mean function and $\mathrm{T}$ test to identify the differences between management and customers in local fast food restaurants regarding the adopted recovery strategies adopted for service failure recovery.

\subsection{Questionnaire Form and sample size}

The study used a questionnaire form to collect data from two categories of respondents. The first category comprised local fast food restaurants' managers and servers. Ten local fast food chains were surveyed as a comprehensive sample (149 restaurants). A total of 123 successful responses were achieved with a response rate of $82.55 \%$.

The second category comprised local fast food restaurants' customers to assess the beliefs of customers about the same variables that managers had earlier reported. A total of 171 successful responses were achieved out of distributed 250 questionnaire forms, with a response rate of $68.4 \%$.

Cluster sampling was adopted to select the target respondents for the customer's questionnaire form; 25 customers were selected randomly in each local fast food chains. The questionnaires were distributed and collected by researcher from April 10, 2016 to July 25, 2016. Both customer and management questionnaires are divided into three parts comprised a series of Likert scale (1-5 disagree/agree) for statements adopted from previous studies:

Part 1; explains the benefits of service failure recovery strategies.

Part 2; explains failure types during different stages of customer life cycle.

Part 3; explains the different strategies of service failure recovery:

- Customer recovery (satisfied customers).

- Process recovery (improved processes).

- Employee recovery (satisfied staff).

\subsection{Validity and Reliability}

For validity, the survey was piloted on a sample of 20 experts to check its face and content validity. The comments of respondents related to the language and design of the questionnaire were considered in the final form. For reliability, Cronbach's alpha coefficient was calculated and exceeded 0.70 for all questions meaning that the questionnaire results are reliable. 


\section{Results and Discussions}

\subsection{Benefits of service failure recovery}

The study attempts to identify the benefits of service failure recovery strategies as stated by restaurants' management and customers (table: 1).

Table (1) Benefits of service failure recovery

\begin{tabular}{|l|c|c|c|c|}
\hline \multicolumn{1}{|c|}{ Benefits } & $\begin{array}{c}\text { Rest. } \\
\text { personnel } \\
\text { Mean }\end{array}$ & $\begin{array}{c}\text { Customers } \\
\text { 'Mean }\end{array}$ & $\begin{array}{c}\text { T test } \\
\text { value }\end{array}$ & Sig. \\
\hline Encourages more information sharing. & 3.7 & 3.9 & -0.254 & 0.769 \\
\hline Keeps better communication. & 4.5 & 4.6 & -0.263 & 0.622 \\
\hline Produces more trust. & 4.7 & 4.1 & 0.77 & 0.766 \\
\hline $\begin{array}{l}\text { Improves process and fewer failures in } \\
\text { the future }\end{array}$ & 4.2 & 3.40 & 3.1 & 0.00 \\
\hline Reduces significant costs. & 4.2 & 3.1 & 3.5 & 0.01 \\
\hline Enhances brand image. & 4 & 4.4 & -0.88 & 0.818 \\
\hline Mitigates customer dissatisfaction. & 4.4 & 4.2 & -0.55 & 0.624 \\
\hline Makes customers more loyal than before. & 4.4 & 4.6 & -0.88 & 0.688 \\
\hline $\begin{array}{l}\text { Generates positive word-of-mouth } \\
\text { (WOM) }\end{array}$ & 4.7 & 4.8 & -1.01 & 0.795 \\
\hline Repeats purchases. & 4.4 & 4.0 & 0.263 & 0.356 \\
\hline
\end{tabular}

There is no significant difference between opinions of restaurant's management and restaurants' customers in eight out of ten benefits of service failure recovery. Both of them agree that service failure recovery encourages more information sharing and keeps better communication between customers and restaurant management, produces more trust in restaurant management, enhances restaurant brand image, mitigates customer dissatisfaction, increases customer loyalty, generates positive word-of-mouth, and encourages repeat purchasing.

And there are significant differences between opinions of restaurant's management and restaurants' customers in only two of the benefits of service failure recovery. The restaurant management agrees that service failure recovery can improve work process and reduce significant costs, while customer opinions are neutral, i.e. improving work process and reducing costs are benefits for restaurant management and customers can't feel these benefits.

\subsection{Types of service failures}

The study detected the differences between restaurant's management opinion and restaurants' customers regarding the type of service failure occuring in local fast food restaurants (table:2). 
Table (2) Type of service failure in the pre-arrival stage

\begin{tabular}{|l|c|c|c|c|}
\hline \multicolumn{1}{|c|}{ Failure types } & $\begin{array}{c}\text { Rest. personnel } \\
\text { Mean }\end{array}$ & $\begin{array}{c}\text { Customers } \\
\text { 'Mean }\end{array}$ & $\begin{array}{c}\text { T test } \\
\text { value }\end{array}$ & Sig. \\
\hline Pre-arrival stage & & & & \\
\hline $\begin{array}{l}\text { Prior expectation (Advertisement } \\
\text { promises not met) }\end{array}$ & 2.6 & 3.8 & -3.5 & 0.00 \\
\hline Reservation & 2.2 & 2.0 & 0.369 & 0.13 \\
\hline Information & 3.1 & 2.3 & 3.23 & 0.00 \\
\hline communication & 2.6 & 3.5 & -0.698 & 0.07 \\
\hline
\end{tabular}

In the pre-arrival stage the study detected two types of service failure; Prior expectation failures and Communication failures. There are significant differences between customer's opinion and management's opinion in these two failure types ( $\mathrm{p}$ value $<0.05$ ). The customers agree that prior expectation failures occurs (mean $=3.8)$, while the management opinion was neutral $($ mean $=2.6)$, meaning that the management usually gives ad. promises that are not met from the customers point of view. Also, the customer agrees that communication failure occurs (mean $=3.5)$ while the restaurant management opinion was neutral $($ mean $=$ 2.6), that may refer to restaurant policies which do not assign employee for telephone order.

Table (3) Type of service failure in the arrival stage

\begin{tabular}{|l|l|l|l|l|}
\hline \multicolumn{1}{|c|}{ Failure types } & \multicolumn{1}{|c|}{$\begin{array}{c}\text { Rest. personnel } \\
\text { Mean }\end{array}$} & $\begin{array}{c}\text { Customers } \\
\text { 'Mean }\end{array}$ & $\begin{array}{c}\text { T test } \\
\text { value }\end{array}$ & \multicolumn{1}{|c|}{ Sig. } \\
\hline Arrival stage. & & & & \\
\hline Welcoming & 3.7 & 4.1 & -0.258 & 0.12 \\
\hline Atmosphere & 2.2 & 4.1 & -3.01 & 0.00 \\
\hline Assigning seats and table & 3.5 & 4.2 & -0.125 & 0.13 \\
\hline Communication with staff & 3.1 & 4.6 & -4.13 & 0.00 \\
\hline
\end{tabular}

The study also affirmed four types of failure during the arrival stage; Welcoming, Atmosphere, Assigning seats and table, and Communication with staff failures. The differences between customer's opinion and management's opinion are not significant in two failure types of them ( $\mathrm{p}$ value $>0.05$ ), as restaurant's management and restaurants' customers agrees that warm welcome and assigning seats and tables failures occur. There are significant differences between customer's opinion and management's opinion in the other two failure types ( $\mathrm{p}$ value $<0.05$ ), as customers agree that atmosphere and communication with staff failure occur (mean $=4.1$ and 4.6 ), and restaurant's management opinion is opposite (mean $=2.2)$ and neutral (mean $=3.1$ ). 


\section{Assessing service failure recovery strategies and its impacts upon service quality offered: management perspective in local Fast food restaurants}

Table (4) Type of service failure in the consuming stage

\begin{tabular}{|l|l|l|l|l|}
\hline \multicolumn{1}{|c|}{ Failure types } & \multicolumn{1}{|c|}{$\begin{array}{c}\text { Rest. personnel } \\
\text { Mean }\end{array}$} & $\begin{array}{c}\text { Customers } \\
\text { 'Mean }\end{array}$ & $\begin{array}{c}\text { T test } \\
\text { value }\end{array}$ & Sig. \\
\hline Consuming stage & 2.8 & 3.8 & -3.5 & 0.03 \\
\hline Time & 2.0 & 3.6 & -1.9 & 0.01 \\
\hline Quality of food & 3.4 & 3.3 & 0.696 & 0.12 \\
\hline Matching prices with service & 2.0 & 4.1 & -2.11 & 0.00 \\
\hline Sequence of service steps & 2.0 & 4.0 & -2.10 & 0.00 \\
\hline Handling of tasks & 2.0 & 4.1 & -2.11 & 0.00 \\
\hline Furnishing of the restaurant & 3.5 & 4.2 & -2.6 & 0.02 \\
\hline Communication of staff & & &
\end{tabular}

In the third stage of customer life cycle (Consuming stage), the study assured the occurrence of 6 out of 7 types of failures (Time, Quality of food, Sequence of service steps, Handling of tasks, Furnishing of the restaurant, Communication of staff failures). There are significant differences between customers' opinion and restaurant management opinion in five of these types of failures, as customers agrees on the occurrence of Time, Quality of food, Sequence of service steps, Handling of tasks, Furnishing of the restaurant failures, while management opinion disagrees about quality of food, Sequence of service steps, Handling of tasks, Furnishing of the restaurant failures and neutral in time failures. On the other hand customers and management agrees on the occurrence of communication with restaurant staff failures.

Table (5) Type of service failure in the departure stage

\begin{tabular}{|l|c|c|c|c|}
\hline \multicolumn{1}{|c|}{ Failure types } & $\begin{array}{c}\text { Rest. personnel } \\
\text { Mean }\end{array}$ & $\begin{array}{c}\text { Customers } \\
\text { 'Mean }\end{array}$ & $\begin{array}{c}\text { T test } \\
\text { value }\end{array}$ & Sig. \\
\hline Departure stage & & & & \\
\hline Accuracy of charges & 2.0 & 4.6 & -2.33 & 0.00 \\
\hline Warm goodbye & 2.2 & 4.0 & -2.34 & 0.00 \\
\hline $\begin{array}{l}\text { Defects of dietary information (allergy } \\
\text { problems) }\end{array}$ & 3.4 & 4.1 & -2.88 & 0.03 \\
\hline
\end{tabular}

In the last stage of customer life cycle, the study assured that restaurant managers agree that worm goodbye and defects of dietary information failures occur and strongly agree on the occurrence of accuracy of charges failures and argued that there is a significant difference between customers and management opinions as management disagrees that accuracy of charges failures and worm goodbye failure occur while shows a neutral opinion on the occurrence of detection of dietary information failures.

\subsection{Service failures recovery strategies}

The study also attempted to identify the service failure recovery strategies used in local fast food restaurant in Egypt from two points of view (restaurant's management, and restaurants' customers) and to find the 
significance of differences between them. In this part researchers divided the recovery strategies into three types which include;

\subsubsection{Customer recovery strategies.}

Table (6) service failure's customer recovery strategies.

\begin{tabular}{|l|l|l|l|l|}
\hline \multicolumn{1}{|c|}{$\begin{array}{c}\text { Customer recovery } \\
\text { strategies }\end{array}$} & $\begin{array}{c}\text { Rest. personnel } \\
\text { Mean } \\
\text { rs } \\
\text { 'Mean }\end{array}$ & $\begin{array}{c}\text { Custome } \\
\text { T test } \\
\text { value }\end{array}$ & \multicolumn{1}{|c|}{ Sig. } \\
\hline $\begin{array}{l}\text { Acknowledgement that a problem } \\
\text { has occurred. }\end{array}$ & 4.2 & 4.6 & -0.263 & 0.15 \\
\hline $\begin{array}{l}\text { Empathy from a customer's point of } \\
\text { view. }\end{array}$ & 4.4 & 4.6 & -0.254 & 0.12 \\
\hline Apology and saying sorry. & 4.9 & 4.8 & 0.214 & 0.10 \\
\hline Own the problem. & 4.0 & 4.0 & - & - \\
\hline Fix the problem for the customer. & 4.6 & 4.3 & 0.254 & 0.12 \\
\hline $\begin{array}{l}\text { Provide assurance that the problem } \\
\text { should not occur again. }\end{array}$ & 4.8 & 4.4 & 0.215 & 0.21 \\
\hline $\begin{array}{l}\text { Provide compensation depending on } \\
\text { the severity of the problem. }\end{array}$ & 4.7 & 4.5 & 0.244 & 0.14 \\
\hline Effective service guarantee. & 4.1 & 4.6 & -0.235 & 0.13 \\
\hline
\end{tabular}

The study assured the usage of all investigated customer recovery strategies. Also confirmed that the difference between management and customer is not significant ( $\mathrm{p}$ value > 0.05). Both of them agree/strongly agree that to recover restaurant's customers, restaurants' staff should acknowledge that a problem has occurred, be Empathy with a customer's point of view, Apology, Own the problem, Fix the problem for the customer, Provide assurance that the problem should not occur again, Provide compensation and guarantee the effectiveness of service. These results concur with Seawright et al., (2008) who assured the importance of Acknowledgement of the problem, and understanding the problem from the customer's point of view. It also coincides with Zhou et al., (2.13) who argued that saying sorry and showing regret are crucial to the customer recovery, Forbes, (2008) who assured the importance of fixing the problem for the customer, and Dutta et al., (2007) and Hoffman et al., (2003) who showed the impact of providing a refund or compensation for recovering of service failures. 


\subsubsection{Process recovery strategies.}

Table (7) service failure process recovery strategies

\begin{tabular}{|c|c|c|c|c|}
\hline $\begin{array}{l}\text { Process recovery } \\
\text { constant variables }\end{array}$ & $\begin{array}{c}\text { Rest. } \\
\text { personnel } \\
\text { Mean }\end{array}$ & $\begin{array}{l}\text { Customers } \\
\text { 'Mean }\end{array}$ & $\begin{array}{l}\text { T test } \\
\text { value }\end{array}$ & Sig. \\
\hline Evaluating of system's needs for recovery. & 4.1 & 3.2 & 3.4 & 0.00 \\
\hline Assessing recovery potential benefits. & 4.0 & 3.1 & 3.42 & 0.00 \\
\hline Process improvement. & 4.2 & 3.8 & 4.35 & 0.04 \\
\hline $\begin{array}{l}\text { Focusing managerial attention on specific } \\
\text { problem areas. }\end{array}$ & 4.0 & 3.6 & 4.77 & 0.06 \\
\hline $\begin{array}{l}\text { Data collection about both complaints and } \\
\text { operational recovery procedures. }\end{array}$ & 4.1 & 4.0 & 4.3 & 0.12 \\
\hline Assessing the impact after implementation. & 4.2 & 3.8 & 3.62 & 0.08 \\
\hline establishing service benchmarks & 4.5 & 3.6 & 2.88 & 0.02 \\
\hline
\end{tabular}

The study assures the usage of all the investigated process recovery strategies and shows no differences between management and customers opinions in 5 out of 7 investigated recovery strategies; both customers and management agree that local fast food restaurants in Egypt collect data about customer complaints and operational recovery strategies (management mean $=4.1$ and customers mean $=4.0$ ), Focusing managerial attention on problems area (management mean $=4.0$ and customers mean $=3.6$ ), improving work process (management mean $=4.2$ and customers mean $=3.8$ ) and assessing the impact after implementation (management mean $=4.2$ and customers mean $=3.8$ ).

And there are significant differences between management opinions and customer opinions in only two process recovery strategies, as restaurant management agrees on evaluating the work system's needs for recovery while customers opinion was neutral, also restaurant management strongly agrees on establishing service benchmarks while customer only agrees on it.

These results agree with (Battaglia et al., 2012) who assured the importance of collecting data related to service failures and suggested recovery strategies and with Chung-Herrera, (2010) who said that organizations should use the data gleaned from the failure to drive improvements and focus managerial attention on the problem areas. The results also concur with Mattila, (2001) who suggested using ISO 1900 benchmark to identify error-prone processes and avoiding it. 


\subsubsection{Employee recovery strategies.}

Table (8) service failure employee recovery strategies

\begin{tabular}{|l|l|l|l|l|}
\hline \multicolumn{1}{|c|}{$\begin{array}{c}\text { Employee recovery } \\
\text { constant variables }\end{array}$} & \multicolumn{1}{|c|}{$\begin{array}{c}\text { Rest. personnel } \\
\text { Mean }\end{array}$} & $\begin{array}{c}\text { Customers } \\
\text { 'Mean }\end{array}$ & $\begin{array}{c}\text { T test } \\
\text { value }\end{array}$ & \multicolumn{1}{|c|}{ Sig. } \\
\hline Modeling employee behaviors. & 4.0 & 3.7 & 0.326 & 0.16 \\
\hline $\begin{array}{l}\text { Keeping employees' self-esteem, } \\
\text { reputation and autonomy }\end{array}$ & 4.5 & 4.0 & 0.256 & 0.15 \\
\hline Employee empowerment. & 4.2 & 4.0 & 0.263 & 0.21 \\
\hline Raising employee commitment. & 4.8 & 3.2 & 1.97 & 0.00 \\
\hline Continuous skill training. & 4.7 & 4.0 & 0.236 & 0.07 \\
\hline Managing employee diversity. & 4.2 & 4.0 & 0.147 & 0.16 \\
\hline
\end{tabular}

Table (8) confirmed the usage of all the investigated employee recovery strategies which include; modeling employee behaviors, keeping employees' self-esteem, reputation and autonomy, Employee empowerment, raising employee commitment, continuous skill training, and managing employee diversity. There are no significant differences between management and customers in 6 out of 7 employee recovery strategies ( $p$ value $>0.05$ ), as both of restaurant's management and restaurants' customers agree or strongly agree on them. And there is a significant difference between management and customers' opinion in only one employee recovery strategy ( $\mathrm{p}$ value < 0.05 ), which is to raise employee commitment, as restaurant management strongly agrees $($ mean $=4.8)$ while restaurants' customer opinion is neutral $($ mean=3.2).

\section{Recommendations.}

Restaurant management should pay more attention to specific service failure types, which the study assured their occurrence in local fast food restaurant in Egypt:

- Take care of advertisement promise and be sure that it will be met, as it will form customer's prior expectations.

- Assign an order taker for telephone order to facilitate customer communication with restaurant during rearrival stage.

- Front line service staff should be well trained on how to welcome restaurant customers, assign seats, and communicate with customers.

- Restaurant management should pay more attention to their furniture and atmosphere.

- Restaurant management should review their policies related to the sequence and timing of service, and levels of food quality and employees skills to be suitable to customer requirements.

- Dietary information related to each item included in the restaurant menu should highly focused especially these which could cause allergy problems.

Service failure recovery strategies include three types of strategies;

A- Customer recovery strategies such as:

Acknowledging that a problem has occurred, showing empathy, apologizing, owning the problem, fixing the problem for the customer, providing assurance that the problem should not occur again, providing compensation and guaranteeing the effectiveness of service next times.

B- Process recovery strategies such as:

Collecting data about customer complaints and operational recovery strategies, focusing managerial attention on problems area, improving work process, and assessing the impact after implementation

C- Employee recovery strategies such as modeling employee behaviors, keeping employees' self-esteem, reputation and autonomy, employee empowerment, raising employee commitment, continuous skill training, and managing employee diversity. 


\section{References}

Bamford, D. and Xystouri, Tatiana (2005),"A case study of service failure and recovery within an international airline", Managing Service Quality: An International Journal, Vol. 15, Iss. 3, pp. 306-322.

Battaglia, D.; Borchardt, Miriam; Sellitto, M. A. and Pereira, G. M. (2012),"Service recovery: a method for assessing performance", Business Process Management Journal, Vol. 18, Iss. 6, pp. 949 - 963.

Casado, Ana B.; Nicolau, J. L. and Mas, F. J. (2011),"The harmful consequences of failed recoveries in the banking industry", International Journal of Bank Marketing, Vol. 29, Iss 1, pp. 32- 49.

Chung-Herrera, B. G.; Gonzalez, Gabriel R. and Hoffman, K. D. (2010),"When demographic differences exist: an analysis of service failure and recovery among diverse participants", Journal of Services Marketing, Vol. 24, Iss 2, pp. 128-141.

Cunha, M. B. E. and Rego, A., Kamoche, K. (2009),"Improvisation in service recovery", Managing Service Quality: An International Journal, Vol. 19, Iss 6, pp. 657-669.

De Matos, C. A.; Rossi, C. A. V.; Veiga, R. T. and Vieira, V. A. (2009),"Consumer reaction to service failure and recovery: the moderating role of attitude toward complaining", Journal of Services Marketing, Vol. 23, Iss 7, pp. $462-475$.

Du, J., Fan X. and Feng, T. (2010),"An experimental investigation of the role of face in service failure and recovery encounters", Journal of Consumer Marketing, Vol. 27, Iss 7, pp. 584 - 593.

Dutta, K.; Venkatesh, U. and Parsa, H.G. (2007),"Service failure and recovery strategies in the restaurant sector", International Journal of Contemporary Hospitality Management, Vol. 19, Iss 5, pp. 351 -363.

Edvardsson, B.; Tronvoll, B. and Höykinpuro, Ritva (2011),"Complex service recovery processes: how to avoid triple deviation", Managing Service Quality: An International Journal, Vol. 21, Iss 4, pp. 331349.

Forbes, L. P. (2008),"When something goes wrong and no one is around: non-internet self-service technology failure and recovery", Journal of Services Marketing, Vol. 22 Iss. 4, pp. 316 - 327.

Forbes, L. P.; Kelley, S. W. and Hoffman, K. D. (2005),"Typologies of e-commerce retail failures and recovery strategies", Journal of Services Marketing, Vol. 19 Iss 5, pp. 280 - 292.

Harris, Katherine E.; Mohr, L. A. and Bernhardt, K. H. (2006),"Online service failure, consumer attributions and expectations", Journal of Services Marketing, Vol. 20, Iss. 7, pp. $453-458$.

Hess Jr, R. L. (2008),"The impact of firm reputation and failure severity on customers' responses to service failures", Journal of Services Marketing, Vol. 22, Iss 5, pp. 385 - 398.

Hoffman, K. D.; Kelley, S. W. and Chung, B. C. (2003),"A CIT investigation of service scape failures and associated recovery strategies", Journal of Services Marketing, Vol. 17, Iss. 4, pp. 322-340

Johnston, R. and Michel, S. (2008),"Three outcomes of service recovery", International Journal of Operations \& Production Management, Vol. 28, Iss. 1, pp. 79 - 99.

Komunda, M. and Osarenkhoe, A. (2012),"Remedy or cure for service failure? ", Business Process Management Journal, Vol. 18, Iss 1, pp. $82-103$.

La, K. V., and Kandampully, J. (2004),"Market oriented learning and customer value enhancement through service recovery management", Managing Service Quality: An International Journal, Vol. 14, Iss 5, pp. 390-401.

Lewis, B. R.; Reid, I. and Bamford, D. (2006),"Recovering from service failure", Strategic Direction, Vol. 22, Iss 6, pp. 37- 39.

Lewis, Barbara R. and Spyrakopoulos, S. (2001),"Service failures and recovery in retail banking: the customers' perspective", International Journal of Bank Marketing, Vol. 19, Iss 1, pp. 37- 48.

Lin, H.; Wang, Y. and Chang, L. (2011),"Consumer responses to online retailer's service recovery after a service failure", Managing Service Quality: An International Journal, Vol. 21, Iss. 5, pp. 511 -534. 
Mack, Rhonda; Mueller, R.; Crotts, J. and Broderick, Amanda (2000),"Perceptions, corrections and defections: implications for service recovery in the restaurant industry", Managing Service Quality: An International Journal, Vol. 10, Iss 6, pp. 339 - 346.

Magnini, V. B.; Ford, J. B.; Markowski, E. P. and Honeycutt Jr, E. D. (2007),"The service recovery paradox: justifiable theory or smoldering myth?", Journal of Services Marketing, Vol. 21, Iss 3, pp. 213 225.

Magnini, V. P. and Ford, J. B. (2004),"Service failure recovery in China", International Journal of Contemporary Hospitality Management, Vol. 16, Iss. 5, pp. 279 - 286.

Mattila, Anna S. (2001),"The effectiveness of service recovery in a multi-industry setting", Journal of Services Marketing, Vol. 15, Iss 7 pp. 583 - 596.

Nguyen, D. T.; McColl-Kennedy, J. R. and Dagger, T. S. (2012),"Matching service recovery solutions to customer recovery preferences", European Journal of Marketing, Vol. 46 Iss 9 pp. 1171 - 1194.

Ozgen, O., and Kurt, S. D. (2012),"Pre-recovery and post-recovery emotions in the service context: a preliminary study", Managing Service Quality: An International Journal, Vol. 22, Iss 6, pp. 592 - 605.

Palmer, A.; Beggs, R. and Keown-McMullan, C. (2000),"Equity and repurchase intention following service failure", Journal of Services Marketing, Vol. 14, Iss 6, pp. 513 - 528.

Primo, M. A. M.; Dooley, K. and Rungtusanatham, M. J. (2007),"Manufacturing firm reaction to supplier failure and recovery", International Journal of Operations \& Production Management, Vol. 27, Iss 3, pp. 323 - 341 .

Santos-Vijande, María L.; Díaz-Martín, Ana M.; Suárez-Álvarez, Leticia; Del Río-Lanza and Ana B. (2013),"An integrated service recovery system (ISRS)", European Journal of Marketing, Vol. 47, Iss. 5/6, pp. $934-963$.

Seawright, K. K.; DeTienne, K. B.; Bernhisel, M. B. and Larson, C. L. H. (2008),"An empirical examination of service recovery design", Marketing Intelligence \& Planning, Vol. 26, Iss 3, pp. 253-274.

Suk, J. B.; Chung, S. H.; Choi, K. and Park, J. (2009),"The Causal Relationship on Quality-centered Organizational Culture and Its Impact on Service Failure and Service Recovery", Asian Journal on Quality, Vol. 10, Iss 1, pp. $37-51$.

Swanson, S. R. and Kelley, S. W. (2001),"Service recovery attributions and word-of-mouth intentions", European Journal of Marketing, Vol. 35, Iss 1/2, pp. 194-211.

Weun, S.; Beatty, S. E. and Jones, M. A. (2004),"The impact of service failure severity on service recovery evaluations and post-recovery relationships", Journal of Services Marketing, Vol. 18, Iss 2, pp. $133-146$

Zhou, Y.; Huang, M.; Tsang, A. S. L. and Zhou, N. (2013),"Recovery strategy for group service failures", European Journal of Marketing, Vol. 47, Iss. 8, pp. 1133 - 1156.

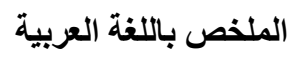

تعد طرق إعادة إنجاح الخدمة هامة جدا لمؤسسات الضيافة. إعادة إنجاح الخدمة تتم وفق ثلاث استراتيجيات هامة تتمحور الأولى حول العميل

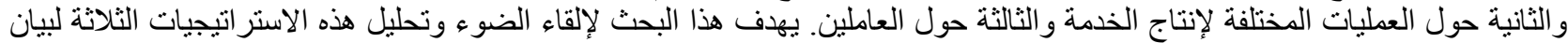

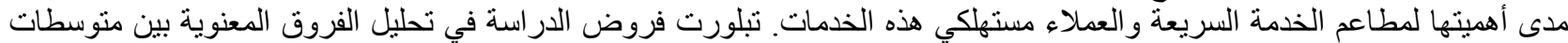

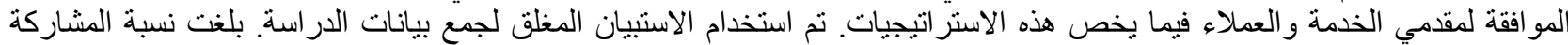

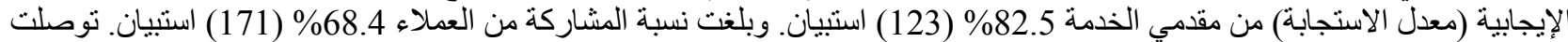

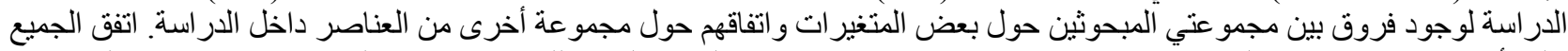

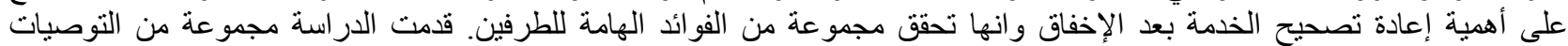
اللار اسات المستقبلة. الكلمات الدالة: صناعة الضيافة و الفنادق، عملية إنجاح الخدمة، الجودة، مطاعم الخدمة السريعة 